\title{
FIRST REPORTS OF SMALLTOOTH SAND TIGER SHARKS, ODONTASPIS FEROX (ELASMO- BRANCHII: LAMNIFORMES: ODONTASPIDIDAE), OFF THE CONTINENTAL ECUADOR
}

\author{
Colombo ESTUPIÑÁN-MONTAÑO ${ }^{1}$, Felipe GALVÁN-MAGAÑA²*, \\ Ana HACOHEN-DOMENÉ ${ }^{3}$, and Jose F. ESTUPIÑÁN-ORTÍZ ${ }^{1}$ \\ ${ }^{1}$ Fundación Alium Pacific, Santiago de Cali, Colombia \\ ${ }_{2}^{2}$ Instituto Politécnico Nacional, Centro Interdisciplinario de Ciencias Marinas, La Paz, Baja California Sur, México
}

${ }^{3}$ Fundación Mundo Azul, Guatemala, Guatemala

\begin{abstract}
Estupiñán-Montaño C., Galván-Magaña F., Hacohen-Domené A., Estupiñán-Ortíz J.F. 2016. First reports of smalltooth sand tiger sharks, Odontaspis ferox (Elasmobranchii: Lamniformes: Odontaspididae), off the continental Ecuador. Acta Ichthyol. Piscat. 46 (3): 251-253.
\end{abstract}

\begin{abstract}
The first report of two smalltooth sand tiger sharks, Odontaspis ferox (Risso, 1810), off the continental Ecuador is presented herewith. The specimens were captured by the Ecuadorian fishing fleet and landed in Manta and Puerto López Canton, Ecuador. The juvenile female specimen was registered in November 2008 and the adult male in July 2009. Both of the specimens recorded extend the geographic range of distribution of $O$. ferox in the tropical eastern Pacific Ocean.
\end{abstract}

Keywords: Ecuadorian biodiversity, range of distribution, new occurrence, Ecuadorian Pacific

The industrial and artisanal fisheries are important economic activities in Ecuador. The city of Manta is the fishing port where the largest volumes of sharks are landed (almost 40000 sharks each year). As many as 30 shark species are caught off the country's coast. Species of the family Alopiidae have the highest catch volumes followed by Carcharhinidae, Sphyrnidae, Triakidae, Squatinidae, and Lamnidae (Estupiñán-Montaño, personal observation).

The family Odontaspididae is distributed in warm temperate and tropical seas with members of this family generally living near the coast and in deep waters. Their wide geographical distribution includes all oceans, coastal waters, and surface and deep waters (down to $1600 \mathrm{~m})$. This family includes two genera: Carcharias and Odontaspis and four species: the sand tiger shark, Carcharias taurus Rafinesque, 1810; the Indian sand tiger shark, Carcharias tricuspidatus Day, 1878; the smalltooth sand tiger shark, Odontaspis ferox (Risso, 1810); and the bigeye sand tiger shark, Odontaspis noronhai (Maul, 1955). All known species of this family are large ( $\geq 360$ $\mathrm{cm}$ total length) (Compagno 1984). In the central eastern Pacific only one species has been identified: Odontaspis ferox, which is distributed from southern California to the Gulf of California (Compagno 1984, Fischer et al. 1995). The smalltooth sand tiger sharks, O. ferox, have also been reported off the coast of Cocos Island, Costa Rica, Malpelo Island, Colombia (Robertson and Allen
2002), the Galapagos Islands, Ecuador (Acuña-Marrero et al. 2013, Ritter and Compagno 2013), and Isla San Ambrosio, Chile (Long et al. 2014).

The presently described findings constitute the first fishing record of Odontaspis ferox off the continental Ecuador. Consequently, the presently reported findings increase the biodiversity of cartilaginous fish off continental Ecuador and expand the range of distribution of the smalltooth sand tiger shark, O. ferox, in Ecuadorian waters and the tropical eastern Pacific Ocean.

The first specimen was reported in the artisanal fishing port of Tarqui Beach in Manta, Ecuador, in 2008 and the second individual was registered in the port of Puerto López Canton, Ecuador, in 2009. Each individual was measured to the nearest $\mathrm{cm}$ and sexed (Table 1). Photographs of the bodies were taken to show more details of the shark's morphological characteristics. Identification of both specimens was aided by the following publications: Compagno (1984), Rubio (1988), Fischer et al. (1995), Chirichigno (1998), Robertson and Allen (2015), and Nelson (2006).

Two specimens of Odontaspis ferox were registered. The first individual was a juvenile female measuring 121 $\mathrm{cm}$ of total length (TL), recorded on 27 November 2008, was landed in the port of Manta, Ecuador (Fig. 1). However, no information is available regarding the catch area or capture method (Fig. 2, Table 1). The second specimen of $O$. ferox was an adult male, $262 \mathrm{~cm}$ TL, captured by

* Correspondence: Dr. Felipe Galván-Magaña, Av. Instituto Politécnico Nacional s/n. Colonia Playa Palo de Santa Rita, La Paz, Baja California Sur, C.P. 23096, México, e-mail: (FGM) galvan.felipe@gmail.com, (CEM) goliathcem@gmail.com, (AHD) anahacohen@gmail.com, (JFEO) felixes55@yahoo.es. 
fishermen on 23 July 2009 (Fig. 3, Table 1). The specimen was captured at a depth of $\sim 14.6 \mathrm{~m}$, at $\sim 1460 \mathrm{~m}$ by using the driftnet method with a mesh size of $12.7 \mathrm{~cm}$. The net was set at night and collected the next morning. The total fishing time was approximately $12 \mathrm{~h}$. Both records were made in the province of Manabí, Ecuador.

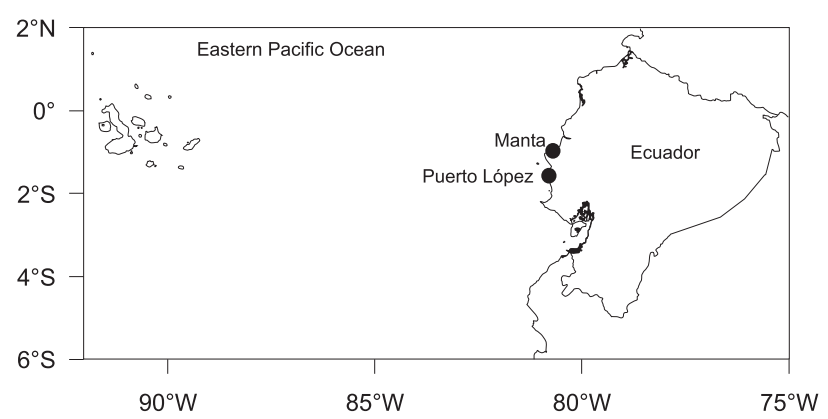

Fig. 1. Landing sites of smalltooth sand tiger shark, Odontaspis ferox, in Ecuador

Table 1

Morphometric characteristics of two specimens of the smalltooth sand tiger shark, Odontaspis ferox, caught off the coast of Ecuador (Measured in $\mathrm{cm}$ )

\begin{tabular}{lcc}
\hline \multicolumn{1}{c}{ Parameter } & Specimen 1 & Specimen 2 \\
\hline Sex & Female & Male \\
Maturity & Juvenile & Adult \\
Total length & 121 & 262 \\
Fork length & 101.4 & 225 \\
Precaudal length & 87.4 & 192 \\
Interdorsal length & 20 & 44 \\
Clasper length & & 19 \\
\hline
\end{tabular}

Specimen 1 was captured on 27 November 2008 and Specimen 2on 23 July 2009.

Odontaspis ferox has been reported off the coast of the Hawaiian Islands, southern California and the Gulf of California (Compagno 1984, Fischer et al. 1995) in North America; Malpelo Island, Colombia (Allen and Robertson 2015); Galapagos Islands, Ecuador (Acuña-Marrero et al. 2013, Ritter and Compagno 2013), and San Ambrosio Island, Chile (Long et al. 2014) in South America.

Odontaspis ferox is characterized by its elongated, bulbous snout and large eyes (Fischer et al. 1995). Their dentition includes two or three pairs of lateral cusps, two pairs of symphysial teeth, and three to four intermediate teeth (Compagno 1984, Fischer et al. 1995). All of these characteristics were observed in specimens recorded in Manta and Puerto López Canton, Ecuador (Figs. 2 and 3). Both specimens had two intermediate teeth and four symphysial teeth, each with two pairs of lateral cusps (Fig. 3 ) and both had large eyes.

Also characteristic of Odontaspis ferox are its large dorsal fins. The first dorsal fin is larger than the second. The origin of the second dorsal fin is located near the end of the base of the pelvic fins (Compagno 1984) with a very evident slot at the caudal peduncle (Fischer et al. 1995).

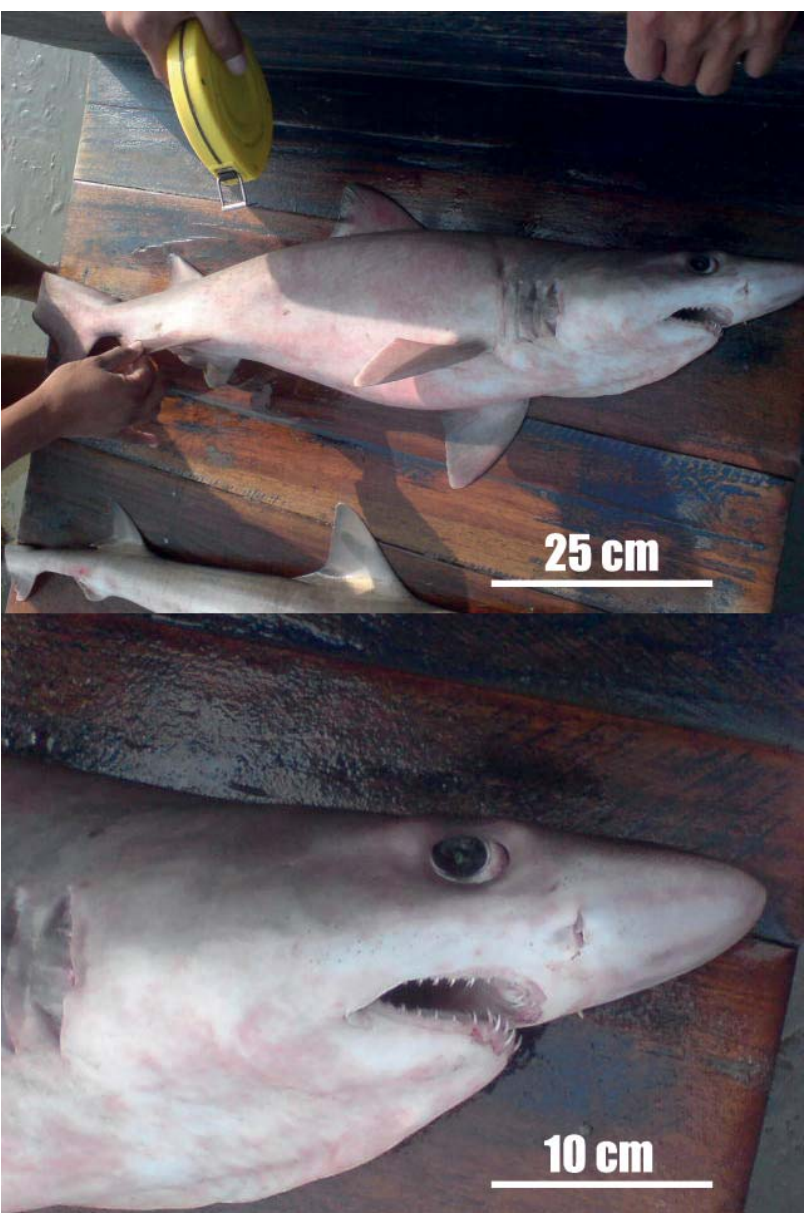

Fig. 2. A juvenile female smalltooth sand tiger shark, Odontaspis ferox, landed in Manta, Ecuador; Specimen 1

These distinctive characteristics were identified in the two specimens landed in Manta and Puerto López Canton (Fig. 3). The dorsal fin was situated behind the pectoral fins and the second dorsal fin was smaller than the first. The origin of the second dorsal fin was above the free end of the pelvic fins and near the end of their bases (Fig. 3). The anal fin was smaller in size than the second dorsal fin (Fig. 3). These characteristics confirm that the specimens registered in Manta and Puerto López Canton corresponds to O. ferox, the species described by Risso (1810).

Odontaspis ferox has been reported off the coasts of oceanic islands, typically volcanic, suggesting the preferences of $O$. ferox for oceanic habitats where it can be found at great depths and at times near the surface (Compagno 1984). Surface behaviour in O. ferox has been observed occasionally in Malpelo Island during recreational and scientific diving at a depth range of 15-30 m (EstupiñánMontaño, personal observation). This behaviour may have led to the capture of the largest specimen $(262 \mathrm{~cm} \mathrm{TL}$, this study) that was captured by using a driftnet at a depth of 10-15 $\mathrm{m}$. The presence of a small O. ferox specimen (121 $\mathrm{cm}$ TL, this study) along with the sighting of two juvenile O. ferox $(<100 \mathrm{~cm} \mathrm{LT})$ in Buenaventura port (Colombia) (Estupiñán-Montaño, unpublished data), suggest that individuals that reside these oceanic islands (e.g., Malpelo and Galápagos Islands) may use these locations as nursery 


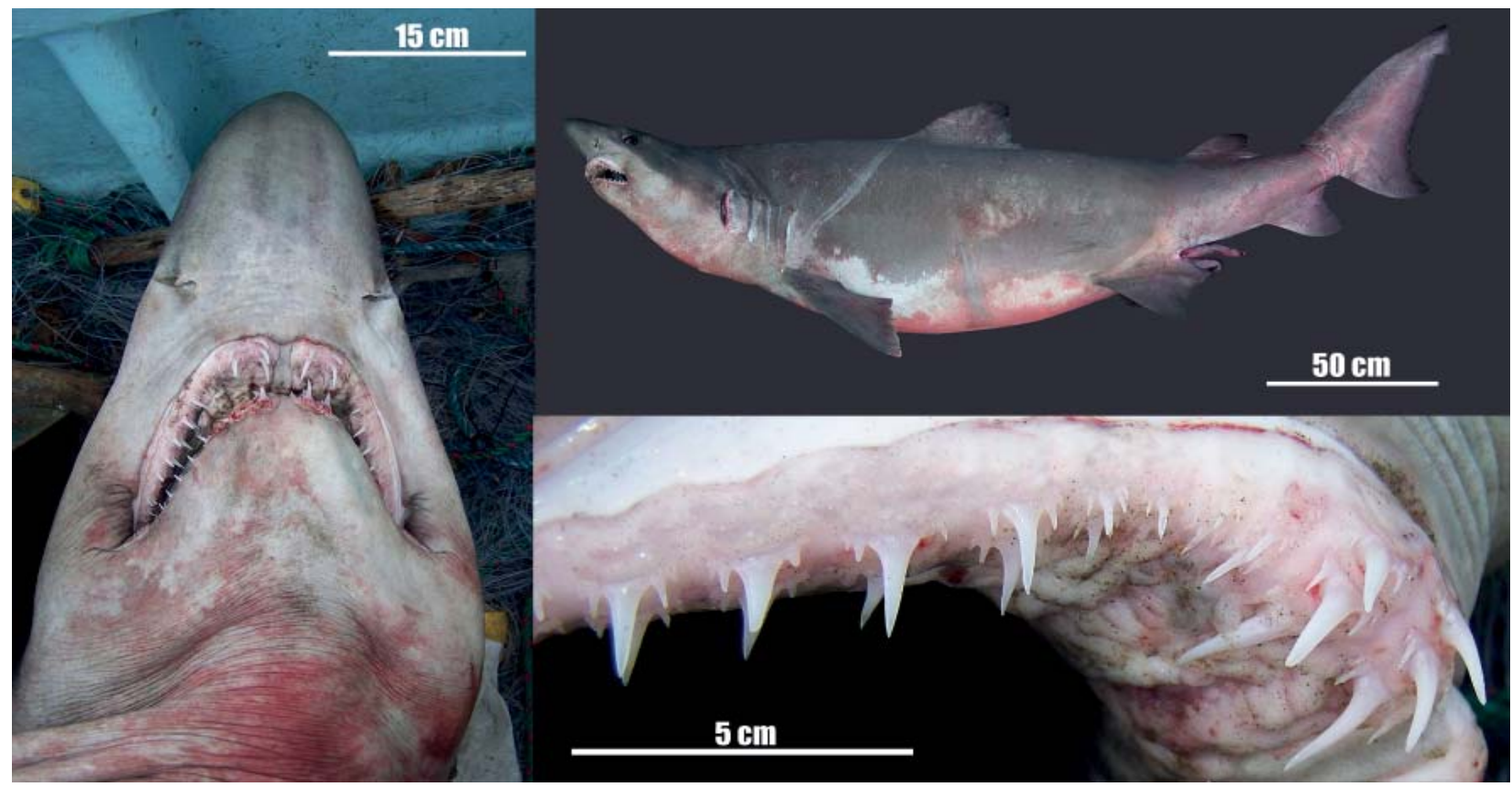

Fig. 3. An adult male smalltooth sand tiger shark, Odontaspis ferox, captured in a driftnet and landed in Puerto López Canton, Ecuador; Specimen 2

areas. However, this hypothesis is yet to be confirmed because there is no available information to support it. Finally, the importance of this study is that it is the first report on the $O$. ferox species in Ecuadorian fishery and in the continental waters of Ecuador. The study expands the $O$. ferox range in the tropical eastern Pacific Ocean.

\section{ACKNOWLEDGEMENTS}

We thank the fishermen from the ports of Manta and Puerto López Canton for providing important information regarding the specimen's capture and permitting us to photograph them. We are also grateful to Vicky Flelitas for her assistance in the field and Anika Mora-Coral for preparing the photographs. FGM thanks the Instituto Politécnico Nacional (IPN; National Polytechnic Institute) for providing fellowships through the Estímulo al Desempeño de los Investigadores (EDI; Performance Incentives) and the Comisión de Operación y Fomento de Actividades Académicas (COFAA; Commission for the Advancement of Academic Activities).

\section{REFERENCES}

Acuña-Marrero D., Zimmerhackel J.S., Mayorga J., Hearn A. 2013. First record of three shark species, Odontaspis ferox, Mustelus albipinnis and Centrophorus squamosus, from the Galápagos Islands. Marine Biodiversity Records 6: e87.

DOI: $10.1017 /$ S1755267213000596

Chirichigno N.F. 1998. Clave para identificar los peces marinos del Perú. Instituto del Mar del Perú, Informe No. 44. 2nd edn. Volumen 3 de Publicacion Especial del Instituto del Mar del Peru, Callao, Peru.

Compagno L.J.V. 1984. FAO species catalogue. Sharks of the world: An annotated and illustrated guide of shark species known to date. Hexanchiformes to
Lamniformes. Pp. 214-222. FAO Fisheries Synopsis No. 125, Vol. 4, Part 1., FAO, Rome.

Fischer W., Krupp F., Schneider W., Sommer C., Carpenter K.E., Niem V.H. 1995. Guía FAO para la identificación de especies para los fines de pesca. Pacífico Centro-Oriental. Vol. 2. Vertebrados, Parte 1. Pp. 647-743. FAO, Rome.

Long D.J., Sala E., Ballesteros E., Caselle J.E., Friedlander A.M., Klapfer A., Blum S., Constable H.B. 2014. Summary of South American records of the smalltooth sand tiger shark Odontaspis ferox (Chondrichthyes: Odontaspididae), with the first record from Chilean waters. Marine Biodiversity Records 7: e67. DOI: $10.1017 / \mathrm{S} 1755267214000700$

Nelson J.S. 2006. Fishes of the world. 4th edn. John Wiley and Sons, New York, NY, USA.

Risso A. 1810. Ichthyologie de Nice, ou histoire naturelle des poisons du Departement des Alpes Maritimes. F. Schoell Paris, France.

Ritter E., Compagno L.J.V. 2013. First record of a smalltooth sandtiger shark, Odontaspis ferox, from the Galápagos Islands. Marine Biodiversity Records 6: e130. DOI: $10.1017 / \mathrm{S} 1755267213001115$

Robertson D.R., Allen G.R. 2015. Peces costeros del Pacífico Oriental Tropical: Un sistema de información. Instituto Smithsonian de Investigaciones Tropicales. Balboa, Panamá. [CD-ROM].

Rubio R.E. 1988. Peces de importancia comercial para el Pacífico Colombiano. Departamento de Biología. Universidad del Valle, Cali, Colombia.

Received: 7 June 2016

Accepted: 19 August 2016 Published electronically: 30 September 2016 